\title{
The Influence of Organizational Capabilities, Strategic Management Accounting on Organizational Performance Mediated by Competitive Advantage in Companies in Indonesia
}

\author{
Farid Wajdi $^{*}$ Regina Jensen Arsjah ${ }^{2}$ \\ 1. Student of the Economic Doctoral Program in Accounting Concentration, Trisakti University, Jakarta, \\ Indonesia \\ 2. Trisakti University Faculty of Economics and Business, Jakarta, Indonesia \\ *farid_wajdi@yahoo.co.id
}

\begin{abstract}
:
The objective of this study is to examine and analyze the role of competitive advantage in mediating the relationship of the influence of organizational capabilities and strategic management accounting (SMA) on organizational performance (OP). The hypotheses testing used partial least square (PLS). We conducted an empirical study to 108 companies in Indonesia. The findings indicated competitive advantage could bring impact by mediation on organizational performance (OP). In this study, found that competitive advantage used in Organizational Capability (OC) and Strategic Management Accounting (SMA) could influence organizational performance (OP). Surprisingly, the influence of organizational capabilities provides a full mediating effect on improvement in organizational performance (OP) through Competitive Advantage (CA), while strategic management accounting (SMA) on organizational performance (OP) could provide a partial mediating role on improvement of organizational performance through competitive advantage.
\end{abstract}

Keyword: Organizational Capabilities, Competitive Advantage, Strategic Management Accounting (SMA) and organizational performance (OP).

DOI: $10.7176 /$ RJFA/10-22-17

Publication date: November $30^{\text {th }} 2019$

\section{Introduction}

Faster technology and information systems have grown as the competition has become increasingly close, forcing companies into using new management techniques (Baykasoğlu and Kaplanoğlu 2008). In Indonesia the application of strategic management accounting is still rarely done specifically for industrial companies (Irawan, 2017).

Dicky and Martusa (2011) said that one strategy that must be done by companies today to be able to compete in global business is to reduce costs, increase productivity, improve product quality and increase the capability to respond to customer needs. Having competitive advantage is one way to win business competition. This competitive advantage can be made in various ways, such as providing good quality, lower price, satisfying customer service and others.

Li et al. (2006) said that in their study competitive advantage was the capability to earn economic profit more than those able to achieve by competitor in the market in the same industry by using delivery dependability indicator, innovative product and time to market.

Organizational performance is an important thing in increasing competition of every company to perform strategies in winning competition and be able to use effective and efficient resources, thus they can achieve the company's vision and mission that can be achieved (Junaidi 2002). This is a goal, namely how companies can improve organizational performance, thus they can make irrelevant revisions or policies to be better in the future (Hongren, et al 2009).

In the previous study are were several differences in the result of the study, namely from the study conducted by Baker and Sinkula (1999) and Jiménez-Jimenez, et al (2008), suggesting that market orientation did not significantly influence organizational performance.

Previous study showed that Organizational Capabilities influenced organizational performance (Ah Lay and Jusoh 2017; Henri 2006). Meanwhile, some previous studies found market orientation was one indicator of organizational capabilities did not influence company performance. (Baker and Sinkula 1999; Jiménez-Jimenez, et al 2008). 
In recent years, strategic management accounting has attracted interest (Cadez 2006). Criticism of conventional management accounting practices which have been widely publicized since the mid-1980s led to an increased interest in strategic management accounting. Strategic management accounting may influence organizational performance, according to Cadez and Guilding (2008). These findings supported the theory of contingency that organizational achievement depends on the suitability of the organization's context and structure.

This study used an analysis unit in the form of individuals, namely managers or finance directors in manufacturing companies in Indonesia. Then, this research will complement the conceptual framework that can explain the relationship between Organizational Capabilities and Competitive Advantage and organizational performance through strategic management accounting, thus it will contribute to the field of management accounting.

\section{Literature Review}

\section{Contingency and Resource-based View (RBV) Theory}

As its inception, the theory of contingency has indicated that the relationship between organizational characteristics and contingency variable has resulted in organizational effectiveness. It has been shown through literature review that several previous studies centered on the study of operational variables as dependent factors influencing accounting information systems.

The development of accounting information system may be affected by contingent variables (Choe, 1998). These variables were divided into the following groups: organizational and individual variables. Organizational variables were organizational structure (Chenhall and Morris, 1986; Gerdin, 2005), duty uncertainties (Chong 1996), organizational strategy (Naranjo 2004) and budget participation (Tsui, 2001). Individual variables were factors that affected the accounting information systems related to individual characteristics.

Resource-based view (RBV) theory was a theoritical concept born from researched economists world-wide, in which this theory is intended to provide a solution that will give a company a competitor advantage as a collection of company resoutces and capabilities (Penrose, 1985; (Wernerfelt 1984).

RBV theory explained the internal resources of the company (Fahy, 2000). The company's success or failure was largely influence by the strengths and weaknesses of the company.

The RBV theory has been identified as a concept that explores the company's ability to use the internal resources to create competitive advantage. In order to implement the already developed plans, the organization must manage internal resources consisting of the entire assets capacity, expertise, organization, data and knowledge.

\section{Organizational Capabilities}

Organizational capabilities are a key element in resource-based approach (RBV) of a company. The primary ability to attract competitive advantages, balance and establish changes in demand was recognized in line mit RBV as creativity, organizational development as well as the orientation towards the business and enterprise (Henri 2006). This ability must be combined to help business become more competitive (Henri 2006; Hult and Ketchen 2001; Hurley et al. 1998)because the talent of each person was not sufficient to establish a sustainable advantage.

When market orientation is complemented by entrepreneurship encouragement, the relationship between resources lead to a cultural corporate learning foundation which can be of value to company customers. Expressed and latent customer understanding may lead to innovation, such as the launch of new products and services (Slater and Narver 1995). Nevertheless, the literature on strategic management and strategic marketing had at least 10 alternative models of analysis involving four organizational capacity (Hult, et al 2003). This research followed the Henri (2006) model, which projected that the four capacities are elements which lead jointly to the creation of a stable competitive advantage that would result in improved performance. There are market orientation, entrepreneurship, innovativeness and organizational learning.

\section{Strategic Management Accounting}

As shown by Simonds (1981), strategic management accounting (SMA) was a strategic tool used to develop and monitor business strategies, focusing on accounting management in general and as a tool for assessing the competitive advantage and adding value for business. Namely costing; planning; control and perform; strategicdecision-making; competitors accounting and customer accounting were five indicators that used for measuring strategic management accounting adapted by Cadez and Guilding (2008). 


\section{Competitive Advantage}

The competitive advantage is that a company may retain its position over its competitors (Mcginnis 1999; Porter 1985). It included capacity to separate a company from its rivals and was the product of important management decisions (Tracey, et al 1999). In term of price / cost, quality, delivery and flexible, the empirical literature has consistently identified as important competitive capabilities (Roth and Miller 1990; Skinner 1985; Tracey, et al 1999). Nonetheless, the recent study listed rivalry based on time as an important competitive priority. Time has been established as a source of competitive advantage in Handfield and Pannesi (1994); Kessler and Chakrabarti (1996); Vesey (1991). Koufteros, et al (1997) has outlined the competitive ability research framework based on previous literature and has determinant five dimensions: competitive price, premium price, customer quality, reliable production and innovation in the fields of production. This dimensions have also been explained by Roth and Miller (1990); Tracey, et al (1999). Based on previous study, this study used indicators from Li et al. (2006) namely delivery dependability, innovative products and time to market.

\section{Organizational Performance}

As a better indicator in the assessment of organizational and outcomes could be combined with non-financial and financial measures (Jusoh and Parnell 2008), the study used the following four indicators by Ah Lay and Jusoh (2017) for organizational performance measuring: sales increase, Return on Investment (ROI), cost reduction and new product development.

\subsection{Hypothesis development}

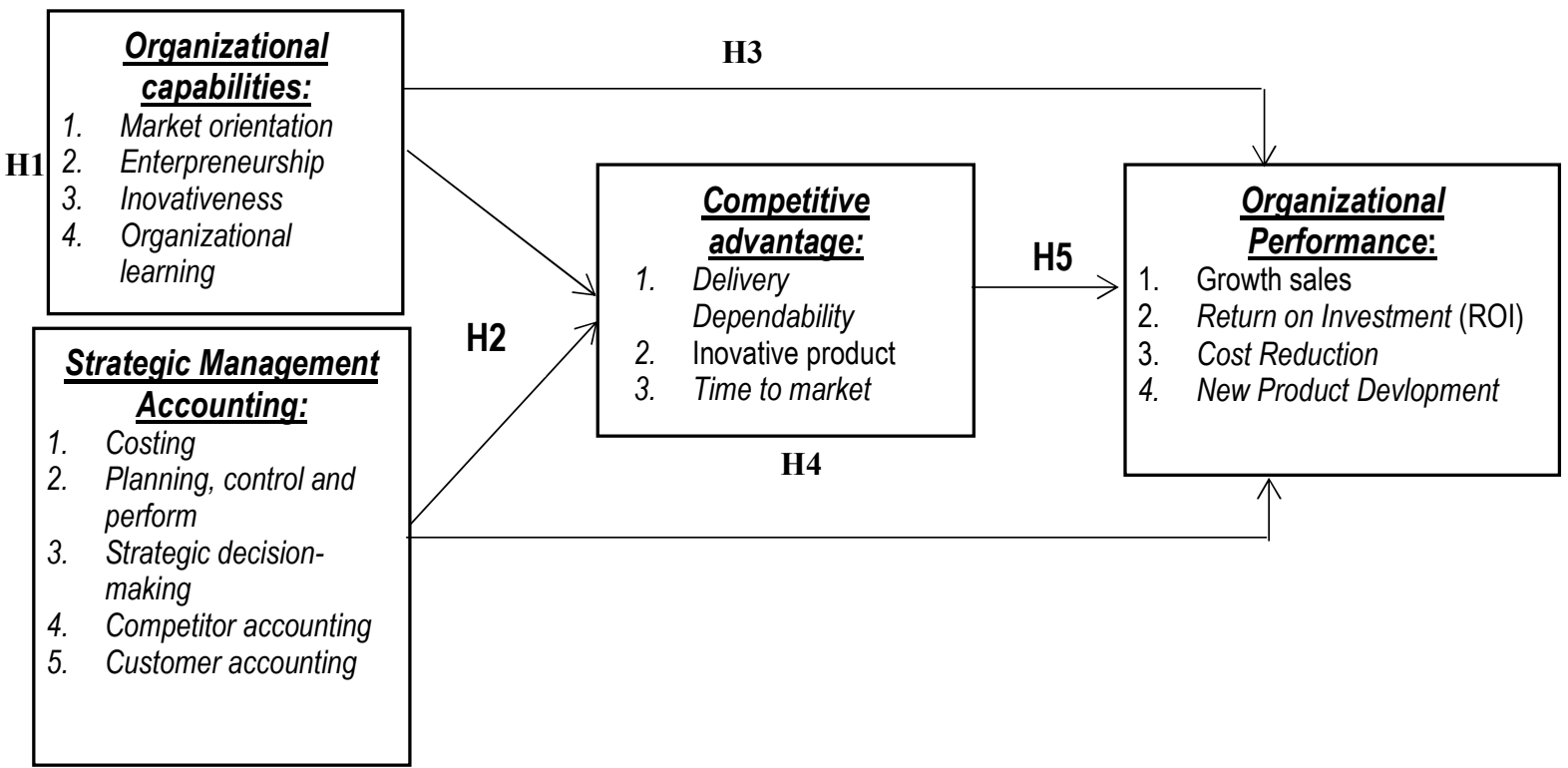

Figure 1. Research model

Anggraini, et al (2014) has shown findings which have affected the business performance of market orientation, creativity and training orientation jointly. Furthermore, the results showed that business performance influences competitive advantages in order to increase competitive advantage directly through increased and higher quality business performance. The role of learning orientation, market orientation and product innovation in competitive advantage were positive influenced (Sismanto 2006). Based on this description this research formulated the following hypothesis:

H1: Organizational capabilities have a positive influence on competitive advantage

Sumarsid (2011) claimed that activity-based costing can prevent companies to calculate the cost of over-costing or undercosting (fees less than they ough to). And the activity-based costing approach can lower the selling price of the product, allowing it to gain competitive advantage. Based on this description this research formulated the following hypothesis:

H2 : Strategic management accounting has a positive influence on competitive advantage. 
Henri (2006) states that organizational capabilities were a fundamental component of company resource-based view (RBV) theory. The main skills for achieving competitive advantage and generating market changes are innovation, organizational learning, market orientation and enterpreneurship according to the RBV. In the report, Ah Lay and Jusoh (2017), who have four organizational capabilities, namely innovation, organizational learning, market orientation and enterpreneurship, concluded that businesses can achieve above-average performance. Based on this description this research formulated the following hypothesis:

H3 : Organizational capabilities have a positive influence on organizational performance

Gandhi Heryanto and Augustine (2014) showed that there was a significant relationship between Management Accounting System and organizational performance. In his study stated that good organizational culture would influence the Management Accounting System fully mediated for organizational performance. In this study it was suggested to look for the dimension of which factor was stronger that influenced organizational performance in relation to the Management Accounting System.

In the two main financial and non-financial quality categories, Alamri (2019) found thet the dimensions of strategy management accounting affected significantly the organization performance. Cadez and Guilding (2012) in their study that the effect on organizational efficiency of atrategic management accounting had a positive and varied influence and relied on different types of groups. Based on this description this research formulated the following hypothesis :

H4 : Strategic management accounting has a positive influence on organizational performance

Based on the description above, the researcher used copetitive advantage as a mediation variable for developing this hypothesis, where the advantages and disadvantages of the results of past studies are considered important to bridge. Agha, et al (2012) research study examined at the relationship between competitive advantage and paints organization, in the United Arab Emirates (UAE). Agha, et al (2012) measured competitive advantage based on two dimensions, namely flexibility and responsiveness, while organizational performance wa measured based on two dimensions, namely growth and profitability.

In the competitive advantage analysis of Adiputra and Mandala (2017), it has a positive and significant influence on organizational performance that means that organizational performance will increase if the competitive advantage increases, and vice versa if organizational performance decrease as well. Based on this description this research formulated the following hypothesis:

H5 : Competitive advantage has a positive influence on organizational performance

H6 : The influence of organizational capabilities on organizational performance through competitive advantage

$H 7$ : the influence of strategic management accounting on organizational performance through competitive advantage.

\section{Methodology}

This analysis unit is a company represented by the director or the company manager. This was carried out by the researcher, thus the validity and reliability of the study could be maintained. In this study the influence of organizational capabilities and strategic management accounting (SMA) variables on organizational performance were mediated by competitive advantages would be analyzed by PLS analysis and for descriptive analysis and trial of instruments by SPSS.

In this case the analysis unit or object to be examined was all companies in Indonesia that were ready to become respondents by replying to questionnaires that the researcher sent to be selected according to the criteria.

Population could be interpreted as the entire subject to be studied or the subject that became the focus of attention of the researcher, as mentioned by Sugiyono (2016), and the population was the region of generalization which included objects or subjects that had certain qualities and characteristics determined by researchers to be further studied and then concluded. The population used in this study were all companies that were ready to become respondents by replying to questionnaires that the researcher sent and engaged in manufacturing, trading and service companies. The total population taken was around 250 companies. Then from the existing population, samples that could represent the population would be taken. The samples were part of the amunt and characteristics possessed by the population, Sugiyono (2016). The sample in this study was 
determined by purposive sampling technique. This technique is one of the non-probability sampling techniques that do not have the same probability to be chosen as a sample. Purposive sampling also determines sampling by specifying specific characteristics that are suitable for the purpose of the study, thus it is expected to answer the problem.

\section{Discussion}

The result of descriptive analysis based on the type of respondent company in table 1 showed that the majority of respondents have a type of company in the industrial sector by $62 \%$ and the rest in the service and trading sectors.

Table 1 Type of Respondent Company

\begin{tabular}{|l|l|l|}
\hline Type of Company & Frekuensi (f) & Persentase (\%) \\
\hline Manufacturing & 67 & 62.0 \\
\hline Services & 29 & 26.9 \\
\hline Commerce & 12 & 11.1 \\
\hline Total & 108 & 100.0 \\
\hline
\end{tabular}

Source: Results of SPSS processing

\section{PLS Analysis}

On the basis of the PLS model estimate in Figure 2, all indicators are charged above 0,7 and therefore all indicators are designed to be valid for construction measurement. In addition to the loading factor value of each indicator, convergent validity from AVE values of each construction was also assessed, and a convergent validity was indicated in the PLS model when the AVE value of each constructed was greater than 0,7 .

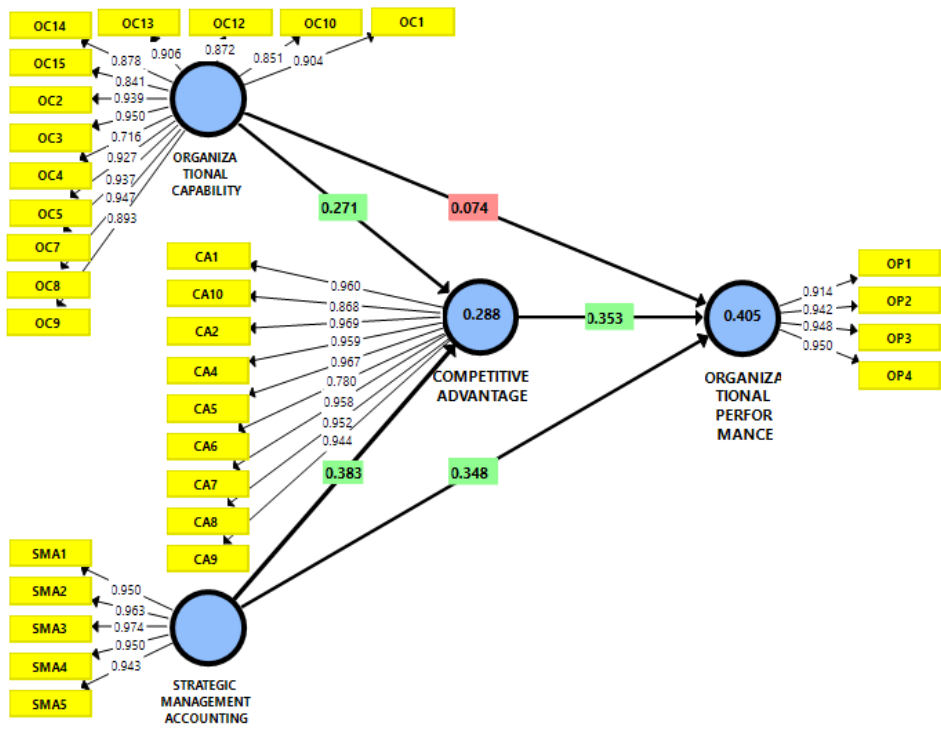

Figure 2 The Result of the PLS Model Estimation after the Invalid Indicator is Removed from the Model

Discriminant validity has been achieved to ensure that every latent variable concept differs from the other variables. If the AVE square value of every exogenous structure (value on the diagonal) exceeds the correlations of the construction and the other construction (values under the diagonal), the model is good discriminant validity. The results were obtained as follows from dicriminant validity testing: 
Table 2 Discriminant validity

\begin{tabular}{|l|l|l|l|l|}
\hline & CA & OP & OC & SMA \\
\hline KB & $\mathbf{0 . 9 3 0}$ & & & \\
\hline KIN & 0.547 & $\mathbf{0 . 9 3 9}$ & & \\
\hline OC & 0.396 & 0.327 & $\mathbf{0 . 8 9 1}$ & \\
\hline SMA & 0.471 & 0.539 & 0.325 & $\mathbf{0 . 9 5 6}$ \\
\hline
\end{tabular}

The results of the discriminant validity in table 2 showed that every construction have AVE square root values above the correlating value with other latent construction, so the discriminating validity could be concluded.

Based on the Alpha Crombachs and composite reliability values of each construct, construction reliability could be assessed. The recommended composite reliability and cronbachs alpha values were more than 0.7 , but in the development study, because the loading factor limit used was low $(0.5)$, the composite values of reliability and alpha crombachs were acceptable as long as the convergent validity requirement and discriminant validity had been fulfilled.

Table 3 Construction realibility

\begin{tabular}{|l|l|l|}
\hline & Cronbach's Alpha & Composite Reliability \\
\hline Competitive advantage & 0.980 & 0.983 \\
\hline Organizational Performance (OP) & 0.955 & 0.967 \\
\hline Organizational Capabilities & 0.978 & 0.980 \\
\hline Strategic Management Accounting & 0.977 & 0.982 \\
\hline Source: Results of Smartpls3 processing & &
\end{tabular}

The reliability test results in table 3 showed that all construction has composite reliability values of $>0.7$ and cronbachs alpha of $>0.7$ indicating that all constructs has fulfilled the required reliability.

The test Goodness of fitness model has been continued after the validity and reliability of the construction has been met during the test phase of the external model. The design SMRM price indicates suit PLS models if the SMRS value is $<0,08$ and the model was considered as perfectly fit if the SRMR value of $<0,10$ was met by the PLS model. Based on the goodness test results of the PLS model in table 3, the saturated SRMR value of the model was 0,050 and so the SRMR value estimated had an SRMR value of 0,050. The PLS model was found to be fit, as the saturated model and the etimated model were less than 0,10 , so the hypothesis is appropiate.

Table 4 Fit Model

\begin{tabular}{|l|l|l|}
\hline & Saturated Model & Estimated Model \\
\hline SRMR & 0.050 & 0.050 \\
\hline
\end{tabular}

In order to assess the influnce of exogenous variables on endogenous variables the significance test is used. The following are the hypotheses for this test:

Ho: Exogenous variables do not influence endogenous variables

Ha: exogenous variables influence endogenous variables

Based on the results of the testing, Ho was rejected for $\mathrm{P}$ value $<0,05$ or $\mathrm{t}>1,96$, it was concluded that exogenous variables has a significant impact on endogenous variables, wherease Ho was not rejected for $p$ value $>0,05$ and found that the exogenous variable had not influence endogenous variables.

From the original sample value of each relationship the influence of exogenous on endogenous variables could be seen. If the influence of exogenous on endogenous variables is a positife / unidirectional effect, while the original sample is negative, the direction of exogenous influence relationship is the contrary. 
The result of estimated model as a reference for testing the hypothesis in this study could be seen in Figure 2 where there was 1 path with a $\mathrm{T}$ value below 1.96, while the other lines had a $\mathrm{T}$ value of $>1.96$.

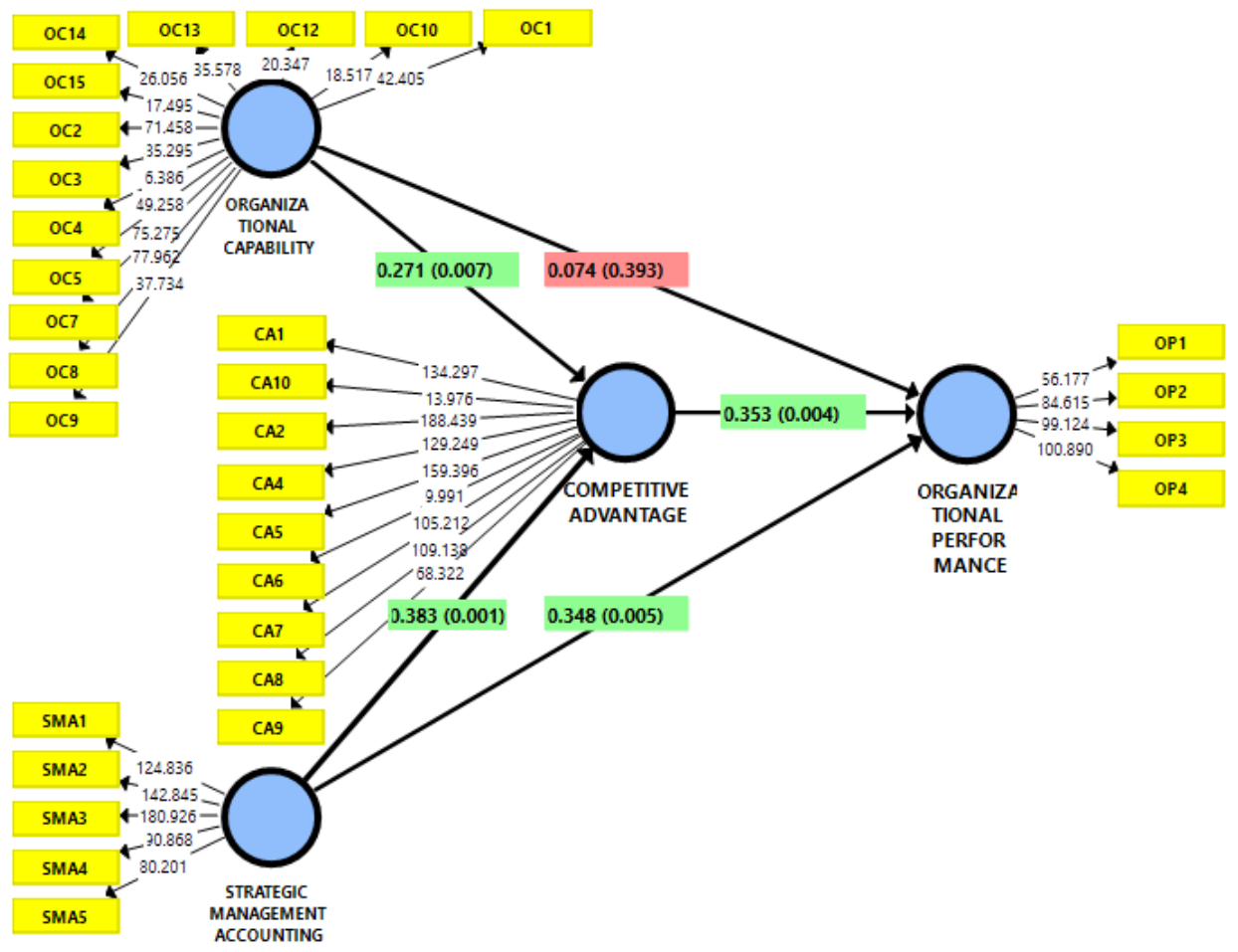

Figure 3 Estimated result of the PLS model with bootstrapping techniques

Table 5 Results of Direct Effect Significance Test and Result of Mediation Influence

\begin{tabular}{|l|l|l|l|l|l|}
\hline Variabel & $\begin{array}{l}\text { Original } \\
\text { Sample }(\mathrm{O})\end{array}$ & $\begin{array}{l}\text { Sample Mean } \\
(\mathrm{M})\end{array}$ & $\begin{array}{l}\text { Standard } \\
\text { Deviation } \\
(\text { STDEV })\end{array}$ & $\begin{array}{l}\text { T-Statistics } \\
(\text { O/STDEV) }\end{array}$ & P Values \\
\hline CA -> OP & 0.353 & 0.340 & 0.123 & 2.867 & 0.004 \\
\hline OC -> CA & 0.271 & 0.270 & 0.101 & 2.690 & 0.007 \\
\hline OC -> OP & 0.074 & 0.083 & 0.087 & 0.854 & 0.393 \\
\hline SMA -> CA & 0.383 & 0.396 & 0.114 & 3.374 & 0.001 \\
\hline SMA -> OP & 0.348 & 0.350 & 0.124 & 2.812 & 0.005 \\
\hline OC -> CA -> OP & 0.096 & 0.090 & 0.046 & 2.074 & 0.039 \\
\hline SMA -> CA -> OP & 0.135 & 0.136 & 0.067 & 2.007 & 0.045 \\
\hline
\end{tabular}

Source: Results of Smartpls3 processing

Based on result in table 5, p-value is 0,007 and $\mathrm{T}$ statistic 2,690 and a positive line coefficient of the influence of organizational capability on competitive advantage ( $\mathrm{OC} \rightarrow \mathrm{CA}$ ). Because $\mathrm{p}$ value $<0,05$ and $\mathrm{T}$ statistic $>1,96$ and the line of coefficient is positive, Ho was rejected, concluding that organizational capabilities influence the company's competitive advantage in a positive and significant. It showed that the greater organizational capabilities, the greater company's competitive advantage. This support hypothesis 1 so hypothesis 1 is accepted.

Based on result in table 5, p-value is 0,001 and $\mathrm{T}$ statistic 3,374 and a positive line coefficient of the influence of strategic management accounting on competitive advantage (SMA $\rightarrow$ CA). Because $p$ value $<0,05$ and T statistic 
$>1,96$ and the line of coefficient is positive, Ho was rejected, concluding that strategic management accounting influence the company's competitive advantage in a positive and significant. The more the strategic management accounting used to be implemented to an organization, the higher the competitive advantage of the company This support hypothesis 2 so hypothesis 2 is accepted.

Based on result in table 5, p-value is 0,393 and $\mathrm{T}$ statistic 0,854 and a positive line coefficient of the influence of organizational capability on organizational performance $(\mathrm{OC} \rightarrow \mathrm{OP})$. Because p value $>0,05$ and $\mathrm{T}$ statistic $<$ 1,96 and the line of coefficient is positive, Ho was not rejected, concluding that organizational capability cannot influence organizational performance in a positive and significant. This does not support hypothesis 3 so hypothesis 3 is not accept.

Based on result in table 5, p-value is 0,005 and $\mathrm{T}$ statistic 2,812 and a positive line coefficient of the influence of strategic management accounting on organizational performance (SMA $\rightarrow$ OP). Because $p$ value $<0,05$ and $T$ statistic $>1,96$ and the line of coefficient is positive, Ho was rejected, concluding that strategic management accounting influence organizational performance in a positive and significant. It indicates that the increasing the organizational performance the more the strategic management accounting relates to an organization.This support hypothesis 4 so hypothesis 4 is accepted.

Based on result in table 5, p-value is 0,004 and $\mathrm{T}$ statistic 2,867 and a positive line coefficient of the influence of competitive advantage on organizational performance $(\mathrm{CA} \rightarrow \mathrm{OP})$. Because $\mathrm{p}$ value $<0,05$ and $\mathrm{T}$ statistic $>1,96$ and the line of coefficient is positive, Ho was rejected, concluding that competitive advantage influence organizational performance in a positive and significant. It shows that the greater the competitive advantage of the company, the greater the corporate performance.This support hypothesis 5 so hypothesis 5 is accepted.

In this study, the competitive advantage variables are used as intervening variables. This shows variables that indirectly influence organizational capability and strategic management accounting for organizational performance, mediated by competing performance variables.

Based on result in table 5, p value is 0,039 of organizational capabilities on organizational performance through competitive advantage $(\mathrm{OC} \rightarrow \mathrm{CA} \rightarrow \mathrm{OP})$. Because $\mathrm{p}$ value $<0,05$, it can be concluded that competitive advantage can mediate indirect influence of organizational capabilities on organizational performance. The results of the test show that, without being mediated by competitive advantage, organizational capabilities can not directly influence organizational performance, thereby mediating the nature of the competitive advantage in the indirect influence of organizations in relation to the direct effects of organizational capabilities on organizational performance of the previous test is full mediating.

Based on result in table 5, p value is 0,045 of stategic management accounting on organizational performance through competitive advantage (SMA $\rightarrow$ CA $\rightarrow$ OP). Because $p$ value $<0,05$, it can be concluded that competitive advantage can mediate indirect influence of strategic management accounting on organizational performance. The results of the test show that, without being mediated by competitive advantage, strategic management accounting can directly influence organizational performance, thereby mediating the nature of the competitive advantage in the indirect influence of organizations in relation to the direct effects of organizational capabilities on organizational performance of the previous test is partial mediating.

\section{Conclusion}

The results of this study can be concluded namely, (1) organizational capabilities influence the company's competitive advantage in a positive and significant. It showed that the greater organizational capabilities, the greater company's competitive advantage. (2) strategic management accounting influence the company's competitive advantage in a positive and significant. The more the strategic management accounting used to be implemented to an organization, the higher the competitive advantage of the company. (3) organizational capability cannot influence organizational performance in a positive and significant. (4) strategic management accounting influence organizational performance in a positive and significant. It indicates that the increasing the organizational performance the more the strategic management accounting relates to an organization.(5) competitive advantage influence organizational performance in a positive and significant. It shows that the greater the competitive advantage of the company, the greater the corporate performance. (6) Competitive advantages can mediate organizational indirect influence on organizational performance. When related to the direct influence of organizational capabilities variables on organizational performance in the previous test, the test result showed that without being mediated by competitive advantage variables, (7) the organizational capabilities variables cannot directly influence the organizational performance, thus the nature of mediation of competitive advantage variables on the indirect influence of organizational capabilities variables on 
organizational performance (OP) is full mediating. (8) Competitive advantages can mediate the indirect influence of strategic management accounting on organizational performance. When related to the direct effect of the strategic management accounting variables on organizational performance in the previous test, the test result showed that without being mediated by the competitive advantage variables, the strategic management accounting variables can also directly influence the organizational performance, thus the nature of mediation from the competitive advantage variables on the indirect influence of strategic management accounting variables on the organizational performance is partial mediating.

Future study should be able to continue this study by adding staff competency and human capital variables, thus these variables have the potential to increase organizational performance and the number of samples should be multiplied, thus the future study can be generalized.

There are several limitation to this study, namely (1) sample size in this study was relatively small, (2) the sample was chosen based on an empirical method, which contained the creation of samples through rational choices to be investigated individually because we did not have a precisely targeted list of the board of directors because we only sent via e-mail (3) the scale of measurement in this study used a subjective measure formed from perceptions of respondents so as to cause bias, (4) the sample in this study was not known by the board of directors in term of their understanding to the management accounting science, thus it is difficult to measure, such as staff competency and human capital.

\section{References}

Adiputra, I Putu Pratama, and Kastawan Mandala. 2017. "Pengaruh Kompetensi Dan Kapabilitas Terhadap Keunggulan Kompetitif Dan Kinerja Perusahaan.” 6(11): 6090-6119.

Agha, Sabah, Laith Alrubaiee, and Manar Jamhour. 2012. "Effect of Core Competence on Competitive Advantage and Organizational Performance." International Journal of Business and Management 7(1): $192-204$.

Ah Lay, Tan, and Ruzita Jusoh. 2017. “Organizational Capabilities, Strategic Management Accounting and Firm Performance.” Jurnal Akuntansi dan Keuangan Indonesia 14(2): 222-46.

Alamri, Ahmad Mohammed. 2019. "Association between Strategic Management Accounting Facets and Organizational Performance.” Baltic Journal of Management 14(2): 212-34.

Anggraini, Nia, Marnis, and Samsir. 2014. "Strategi Orientasi Pasar, Inovasi Dan Orientasi Pembelajaran Pengaruhnya Terhadap Kinerja Usaha Serta Dampaknya Terhadap Keunggulan Bersaing ( Studi Pada Industri Jasa Salon Kecantikan Dan Spa Di Kota Pekanbaru ).” Jurnal Sosial Ekonomi Pembangunan 4(12): 295-310.

Baker, William, and James Sinkula. 1999. "Learning Orientation, Market Orientation, and Innovation: Integrating and Extending Models of Organizational Performance." Journal of Market-Focused Management 4(4): 295-308.

Baykasoğlu, Adil, and Vahit Kaplanoğlu. 2008. "Application of Activity-Based Costing to a Land Transportation Company: A Case Study.” International Journal of Production Economics 116(2): 308-24.

Cadez, Simon. 2006. "A Cross-Industry Comparison of Strategic Management Accounting Practices: An Exploratory Study." Economic and Business Review for Central and South-Eastern Europe 8(3): 279.

Cadez, Simon, and Chris Guilding. 2008. "An Exploratory Investigation of an Integrated Contingency Model of Strategic Management Accounting." Accounting, Organizations and Society 33(7-8): 836-63. http://dx.doi.org/10.1016/j.aos.2008.01.003.

_. 2012. "Strategy, Strategic Management Accounting and Performance: A Configurational Analysis." Industrial Management and Data Systems 112(3): 484-501.

Chenhall, R.H, and D Morris. 1986. "Chenhall, R. H., \& Morris, D. (1986). The Impact of Structure, Environment and Interdependence on the Perceived Usefulness of Management Accounting Systems. The Accounting Review, 61, 16-35.” The Accounting Review 61: 16-35.

Choe, Jong Min. 1998. "The Effects of User Participation on the Design of Accounting Information Systems." Information and Management 34(3): 185-98.

Chong, Vincent K. 1996. "Management Accounting Systems, Task Uncertainty and Managerial Performance: A Research Note.” Accounting, Organizations and Society 21(5): 415-21. 
Dicky, Yoanes, and Riki Martusa. 2011. "Penerapan Activity Based Costing (ABC) System Dalam Perhitungan Profitabilitas Produk.” 3(1).

Gandhi Heryanto, and Yvonne Augustine. 2014. "The Influence of Organizational Culture on Corporate Performance:Using Management Accounting System as the Mediating Variable." OIDA International Journal of Sustainable Development.

Gerdin, Jonas. 2005. "Management Accounting System Design in Manufacturing Departments: An Empirical Investigation Using a Multiple Contingencies Approach.” Accounting, Organizations and Society 30(2): 99-126.

Handfield, R. B., and R. T. Pannesi. 1994. "Antecedents of Leadtime Competitiveness in Make-to-Order Manufacturing Firms." International Journal of Production Research 32(12): 511-37.

Henri, Jean François. 2006. "Management Control Systems and Strategy: A Resource-Based Perspective." Accounting, Organizations and Society 31(6): 529-58.

Hongren, Charles T, Gary L Sundem, and Frank H Selto. 2009. "Management Accounting." New Jersey, Prentice Edition.

Hult, G. Tomas M., and David J. Ketchen. 2001. "Does Market Orientation Matter?: A Test of the Relationship between Positional Advantage and Performance." Strategic Management Journal 22(9): 899-906.

Hult, G. Tomas M., Charles C. Snow, and Destan Kandemir. 2003. "The Role of Entrepreneurship in Building Cultural Competitiveness in Different Organizational Types.” Journal of Management 29(3): 401-26.

Hurley, Robert F, G Tomas M Hult, Eric Abrahamson, and Sarah Maxwell. 1998. "Innovation , Learning : An Organizational and Empirical Integration Examination.” Journal of Marketing 62(3): 42-54.

Jiménez-Jimenez, Daniel, Raquel Valle Sanz, and Miguel Hernandez-Espallardo. 2008. "Fostering Innovation: The Role of Market Orientation and Organizational Learning." European Journal of Innovation Management 11(3): 389-412.

Junaidi. 2002. "Kontribusi Penerapan Balanced Scorecard Terhadap Peningkatan Kinerja Perusahaan (Studi Kasus Di Perusahaan Jasa Perantara Asuransi-PT. XYZ).” Universitas Bina Nusantara.

Jusoh, Ruzita, and John A. Parnell. 2008. 46 Management Decision Competitive Strategy and Performance Measurement in the Malaysian Context: An Exploratory Study.

Kessler, Eric H., and Alok K. Chakrabarti. 1996. "Innovation Speed: A Conceptual Model of Context, Antecedents, and Outcomes." Academy of Management Review 21(4): 1143-91.

Koufteros, X.A, M.A Vonderembse, and W.J Doll. 1997. "Competitive Capabilities: Measurement and Relationship.” Proceedings Decision Science Institute, Atlanta, GA, USA: 1067-68.

Li, Suhong, Bhanu Ragu-Nathan, T. S. Ragu-Nathan, and S. Subba Rao. 2006. "The Impact of Supply Chain Management Practices on Competitive Advantage and Organizational Performance.” Omega 34(2): 107-24.

Mcginnis, Michael A. 1999. "Purchasing and Supplier Involvement in Process Improvement: A Source Of." Management: 42-50.

Naranjo. 2004. "The Role of Sophisticated Accounting System in Strategy Management." The International Journal of Digital Accounting Research 4(June): 125-44.

Penrose, ET. 1985. "The Theory of the Growth of the Firm: Twenty Five Years After." Acta Universitatis Upsaliensis: Studia Oeconomicae Negotiorum (Upsala Lectures in Business) 20: 1-16.

Porter, Michael E. 1985. Competitive Advantage: Creating and Sustaining Superior Performance. New York: Free Press; London : Collier Macmillan. http://id.lib.harvard.edu/alma/990004736830203941/catalog.

Roth, Aleda V, and Jeffrey G Miller. 1990. "Manufacturing Strategy, Manufacturing Strength, Managerial Success, and Economic Outcomes.” Manufacturing Strategy: 97-108.

Simonds, Kenneth. 1981. "Strategic Management Accounting.” Management Aaaccounting 59(4): $26-29$.

Sismanto, Adi. 2006. "Analisis Pengaruh Orientasi Pembelajaran, Orientasi Pasar Dan Inovasi Terhadap Competitive Advantage Untuk Meningkatkan Kinerja Pemasaran (Studi Empiris Pada Industri Kecil Dan Mengengah Produk Makanan Di Provinsi Bengkulu).”Universitas Diponegoro Semarang.

Skinner, W. 1985. Manufacturing: The Formidable Competitive Weapon. New York : John Wiley. 
Slater, Stanley F, and John C Narver. 1995. "Market Orintation and the Learning Organization." Journal of Marketing 59(3): 63-74.

Sugiyono. 2016. Metode Penelitian Kuantitatif, Kualitatif Dan R\&D. Bandung: PT. Alfabet.

Sumarsid. 2011. "Pendekatan Metode Activity Based Costing Pada Perencanaan Harga Pokok Produksi Untuk Memperoleh Competitive Advantage." Jurnal Ilmiah Ekonomi Manajemen dan Kewirausahaan "Optimal” 5(1): 71-90.

Tracey, Michael, Mark A. Vonderembse, and Jeen Su Lim. 1999. "Manufacturing Technology and Strategy Formulation: Keys to Enhancing Competitiveness and Improving Performance." Journal of Operations Management 17(4): 411-28.

Tsui, Judy S.L. 2001. "The Impact of Culture on the Relationship between Budgetary Participation, Management Accounting Systems, and Managerial Performance: An Analysis of Chinese and Western Managers." International Journal of Accounting 36(2): 125-46.

Vesey, J.T. 1991. "The New Competitors : They Think in Terms of Speed-to-Market." Academy of Management Executive 5: 23-33.

Wernerfelt, Birger. 1984. “A Resource-Based View of the Firm.” Strategic management journal 5: 171-80. http://onlinelibrary.wiley.com/doi/10.1002/smj.4250050207/abstract. 